\begin{tabular}{|c|c|c|c|c|}
\hline Submission & Review Process & Revised & Accepted & Published \\
\hline $20-02-2020$ & $25-02 \mathrm{~s} / \mathrm{d} 25-03-2020$ & $28-03-2020$ & $30-12-2019$ & $01-04-2020$ \\
\hline
\end{tabular}

Ampera: A Research Journal on Politics and Islamic Civilization, Vol. 1 No. 2, April 2020 (107-125)

Published by: Politik Islam UIN Raden Fatah Palembang

\title{
Pluralisme Agama dalam Pemikiran Syekh Siti Jenar
}

\author{
Otoman \\ Fakultas Adab dan Humaniora Universitas Islam Negeri Raden Fatah Palembang \\ E-mail:otoman_uin@ radenfatah.ac.id
}

\begin{abstract}
This article discusses the roots of religious pluralism of Sheikh Siti Jenar. As one of the prosecution of Islam in the land of Java, he had a thought of religious pluralism, which is the meeting point of religions on the esoteric landscape (the transcendent unity of religions), in terms of Islamic mysticism known as Wahdat al-Adyan. The author deliberately used pluralism to uncover the thoughts of Sheikh Siti Jenar based on his teachings. The theory of religious pluralism classification, which includes secular humanism, global theology, syncretism, and lasting wisdom, is used to determine the pattern of religious pluralism found in the thought of Sheikh Siti Jenar. The problems discussed in this paper are the thoughts and patterns of religious pluralism Sheikh Siti Jenar. For that purpose, the relevant data, obtained through the literature study, is analyzed using a method of content analysis and descriptive-analytic. Based on the study conducted, it can be suggested that the concept of religious pluralism Sheikh Siti Jenar is the implications of the plurality of scientific networks that accumulate in the developed teachings, Manunggaling Kawulo Gusti. The pluralism in the thought of Sheikh Siti Jenar covered the meeting point of various religions at the esoteric level, because the difference for him only occurred at the level of exoscorers alone. This view when associated with religious pluralism classification belongs to the category of eternal wisdom. The thought of Sheik Siti Jenar about the mystical maqamat in the process of discovering identity, the three elements that build human beings, heaven and hell, and his views on nature, all of which are intertwined with the teachings of Islamic mysticism, Hinduism, Buddhism and Javanese philosophy. The thought of Sheikh Siti Jenar took the pattern of religious pluralism, syncretism.
\end{abstract}

Keywords: Thoughts, teachings, religious pluralism, Sheikh Siti Jenar

\footnotetext{
ABSTRAK

Tulisan ini membahas tentang Akar Pemikiran Pluralisme Agama Syekh Siti Jenar. Sebagai salah seorang pendakwah Islam di tanah Jawa, ia memiliki pemikiran pluralisme agama, yaitu titik temu agama-agama pada tataran esoterik (the transcendent unity of
} 
religions), dalam istilah mistisme Islam dikenal dengan wahdat al-adyan. Kerangka pluralisme sengaja penulis gunakan untuk mengungkap pemikiran-pemikiran Syekh Siti Jenar yang didasarkan pada ajarannya. Teori tentang klasifikasi pluralisme agama, yang mencakup humanisme sekular, teologi global, sinkretisme, dan hikmah abadi, digunakan untuk mengetahui corak pluralisme agama yang terdapat dalam pemikiran Syekh Siti Jenar. Permasalahan yang dibahas dalam tulisan ini adalah pemikiran dan corak pluralisme agama Syekh Siti Jenar. Untuk tujuan itu, maka data-data relevan, yang diperoleh melalui studi kepustakaan, dianalisa menggunakan metode analisis isi dan deskriptif-analitik. Berdasarkan kajian yang dilakukan, dapat dikemukakan bahwa konsep pluralisme agama Syekh Siti Jenar merupakan implikasi dari pluralitas jaringan keilmuan yang terakumulasi dalam ajaran yang dikembangkannya, Manunggaling Kawulo Gusti. Pluralisme dalam pemikiran Syekh Siti Jenar melingkupi titik temu pelbagai agama pada level esoterik, sebab perbedaan itu baginya hanya terjadi pada level eksoterik semata. Pandangan ini bila dikaitkan dengan klasifikasi pluralisme agama termasuk kategori hikmah abadi. Pemikiran Syekh Siti Jenar tentang maqamat mistik dalam proses menemukan jati diri, tiga unsur yang membangun manusia, surga dan neraka, serta pandangannya tentang alam, semuanya berkait berkelindan dengan ajaran mistisme Islam, Hindu, Budha dan filsafat Jawa. Pemikiran Syekh Siti Jenar tersebut mengambil corak pluralisme agama, sinkretisme.

Keywords: Pemikiran, Ajaran, Pluralisme Agama, Syekh Siti

\section{PENDAHULUAN}

Tidak dapat dinafikan bahwa Syekh Siti Jenar masih menjadi tokoh kontroversial di tengah jagad pemikiran Islam Jawa. Menyebabkan Syekh Siti Jenar, hingga kini tetap relevan untuk dikaji. Bukan hanya sosoknya yang diperdebatkan, apakah ia adalah sosok historis yang pernah hidup di negeri ini (khususnya di Tanah Jawa), atau sekedar mitos yang berkembang dan beredar di masyarakat Jawa, namun pemikirannya juga sering kali dipertentangkan dengan Islam murni. Syekh Siti Jenar memang tak pernah meninggalkan karya tulis berjilid-jilid yang bisa dibaca hingga saat ini, namun perihal hidup dan pemikirannya telah sampai kepada kita melalui pelbagai tulisan yang dihasilkan oleh para penulis dewasa ini.

Syekh Siti Jenar sebagaimana dikemukakan oleh John Rinaldi (2008, hal.v); "(Dia) laksana Socrates dari zaman Yunani kuno. Sosok historisnya tidak pernah bisa dibuktikan secara pasti. Informasi tentang dirinya dan pemikirannya banyak diperoleh melalui tulisan-tulisan muridnya, Plato, yang menjadikan Socrates sebagai tokoh utama dalam pelbagai karya tulisnya". Di sisi lain, banyak versi tentang kisah Syekh Siti Jenar semakin mempertebal kabut misteri kehidupannya. Banyak pihak yang meragukan sosok Syekh Siti Jenar, namun satu hal yang pasti, pemikiran, pola pemahaman dan penghayatan ajaran-ajarannya benar-benar ada di tengah kehidupan masyarakat Jawa (Rinaldi 2008, hal.vi).

Memang tidak mudah untuk menjelaskan pemikiran Syekh Siti Jenar di tengah kontroversi pandangan pelbagai pihak terhadapnya. Ada yang menilai, bahwa ajarannya merupakan bentuk penghayatan nilai-nilai ajaran Islam yang disesuaikan dengan kultur di mana penganut Islam itu berada, dalam hal ini Tanah Jawa. Di mana cara memahami Islam Syekh Siti Jenar berbeda dengan cara pandang bangsa Arab memahaminya, sekalipun sumber ajaran itu sama, yakni al-Qur'an dan Sunah Rasul. Bagi pihak-pihak 
yang sejalan dengan pemikiran Syekh Siti Jenar mengukuhkan, bahwa penghayatan dan pengamalan Islam yang demikian itulah yang paling bijaksana, karena tidak meninggalkan kearifan lokal di mana penganut Islam itu berada. Akan tetapi di sisi lain, pihak-pihak yang ingin agar ajaran Islam itu diamalkan sesuai dengan cara yang dilakukan oleh Rasulullah saw. dan para sahabat, memandang bahwa ajaran-ajaran yang disampaikan oleh Syekh Siti Jenar itu bertentangan dengan ajaran Islam.

Namun benarkah demikian? Apakah hanya karena cara yang dipakai Syekh Siti Jenar dalam memahami ajaran Islam berbeda dengan mainstream yang ada, yang pada masa itu tercitrakan pada ajaran yang disampaikan oleh para wali, lalu divonis murtad dan sesat dari ajaran Islam begitu saja dijatuhkan padanya?. Perlu ditegaskan di sini, meskipun sifat umum dari pelbagai fakta bisa ditemukan, namun fakta-fakta sosial selalu menampilkan diri dengan membawa sifat yang tak pernah tunggal (Rinaldi 2008, hal.1). Demikian pula halnya dengan pemahaman, penghayatan dan praktik ajaran Islam, bahkan pada agama-agama lain yang pernah menyejarah dalam kehidupan umat manusia.

Secara sosiologis, sebenarnya agama apa pun akan menghasilkan umat yang model pemahaman dan penghayatan agamanya berbeda-beda sesuai dengan tingkat pluralitas sosialnya. Identitas kelembagaan agama boleh saja sama, namun model keagamaan para penganutnya tidak akan lepas dari pengaruh sejarah sosial, kebudayaan dan keadaan hidup yang dialami pada tempat dan masa yang berbeda. Berbagai macam hal yang membentuk pola keberagamaan itu akan sangat mungkin memengaruhi seorang individu dalam memaknai sumber-sumber ajaran agamanya, dalam hal ini agama Islam adalah al-Qur'an dan Sunah Rasul, sehingga melahirkan perbedaan lebih lanjut dalam tataran praksis. Demikian juga, bila mempelajari pemikiran dan ajaran Syekh Siti Jenar.

Dewasa ini, issue pluralisme agama menjadi fenomena yang membumi di masyarakat. Pluralisme agama berawal dari klaim kebenaran absolut (truth claim absolute) antar agama yang saling berseberangan. Setiap agama mengklaim dirinya yang paling benar, yang lain sesat. Klaim semacam ini melahirkan keyakinan yang biasa disebut "doctrine of salvation" (doktrin keselamatan), bahwa keselamatan atau pencerahan (enlightenment), atau surga merupakan hak para pengikut agama tertentu saja (Thoha 2005, hal.1). Hal ini tidak hanya terjadi antar agama, namun juga pada sekte atau aliran. Kemudian pluralisme agama mengalami pergeseran makna, etimologis maupun terminologis. Secara etimologi diartikan "paham kesetaraan agama-agama", sedangkan secara terminologi didefinisikan sebagai suatu "kondisi hidup bersama (koeksistensi) antaragama yang berbeda-beda dalam satu komunitas dengan tetap mempertahankan ciriciri spesifik atau ajaran-ajaran masing-masing agama" (Thoha 2005, hal. 14). Dalam konteks ini, apabila dikaitkan dengan pemikiran Syekh Siti Jenar, maka akan sangat menarik, karena Islam yang berkembang di Indonesia, tumbuh dan berkembang dalam lingkungan dan pengaruh tradisi lokal. Peralihan agama dari Hindu, Budha, menuju Islam, yang dilakukan oleh para pendakwah senantiasa menjadikan pluralitas masyarakat sebagai rambu-rambu dalam mensosialisasikan Islam sebagai rahmatan lil alamin, sehingga benturan kultur dan agama dapat diminimalisir, bahkan dihindari.

Dalam setiap fase kehidupan manusia, dalam hubungannya dengan agama, lebih khusus pluralisme selalu ada penafsiran-penafsiran yang dianggap nyeleneh dan terkadang menjadi fenomena baru yang digandrungi, bahkan dijadikan landasan bersikap, berbuat, bertindak, dan berpendapat. Namun hal yang tidak boleh dilupakan bahwa selalu ada transformasi pemahaman sejarah untuk memunculkan kembali serta dikaji dalam konteks kekinian. Syekh Siti Jenar dan pemikirannya dapat dikaitkan dengan issue pluralisme agama tersebut. Data yang penulis temukan menunjukkan, bahwa pandangan 
Syekh Siti Jenar sudah banyak diteliti para ahli, baik dalam bentuk ajaran maupun dalam penafsiran keagamaan. Abdul Munir Mulkhan (2004) menyatakan, bahwa jalan sufi merupakan humanisasi Islam bagi semua, dengan mengajukan konsep penafsiran, bahwa praktek sufi ternyata juga tidak dapat menghindari perbedaan di antara penganutnya, bahkan tak jarang menimbulkan konflik keras. Ada kecenderungan genocide atau penghilangan pihak-pihak yang berbeda paham dalam keagamaan, di dalam perbedaan praktek sufi juga, seperti kasus Wali Songo versus Siti Jenar (Mulkhan 2004, hal.10).

Syekh Siti Jenar yang ditunjukkan Mulkhan adalah seorang yang memiliki pandangan semua agama sama, karena janji surga Tuhan terbuka bagi seluruh manusia yang benar-benar ikhlas mengabdikan diri kepada-Nya melalui bentuk-bentuk yang paling jelas, yaitu pembebasan manusia tanpa melihat agama dan partainya dari penderitaan (Mulkhan 2004, hal. 25). Surga Tuhan itu nanti dimungkinkan terdiri dari banyak kamar yang bisa dimasuki dengan beragam jalan atau agama, kata Syekh Siti Jenar (Mulkhan 2004, hal.10). Senada dengan apa yang telah diungkapkan oleh Mulkhan (2004), Sholikhin (2004, hal.10) mengemukakan, bahwa Syekh Siti Jenar mengakomodasi, bahkan sebagian mengadopsi kultur lokal, yang dimasukkan ke dalam tradisi Islam, lalu memunculkan peradaban serta corak keberagamaan yang baru.

Dari uraian di atas, maka tulisan ini akan membahas Akar Pemikiran Pluralisme Agama Syekh Siti Jenar. Suatu usaha untuk menganalisa pemikiran Syekh Siti Jenar dalam kerangka pluralisme agama, berdasarkan klasifikasi yang dikemukakan Thoha (2005, hal.49-108), yaitu humanisme sekular, teologi global, sinkretisme, dan hikmah abadi. Adapun permasalahan yang diketengahkan dalam kajian ini adalah: (1) Bagaimana akar pemikiran pluralisme agama Syekh Siti Jenar?; (2) Bagaimanakah corak pluralisme agama Syekh Siti Jenar?

\section{TINJAUAN LITERATUR}

Berdasarkan telaah penulis terhadap pelbagai literatur yang terkait dengan permasalahan yang diangkat dalam tulisan ini. Belum ada pembahasan khusus yang fokus membahas tentang Pemikiran Pluralisme Agama Syekh Siti Jenar. Meskipun demikian, ada beberapa literatur yang relevan, di antaranya adalah:

Abdul Munir Mulkhan melalui bukunya, Ajaran dan Jalan Kematian Syekh Siti Jenar (2004). Ia berupaya untuk menunjukkan pemikiran keagamaan Syekh Siti Jenar dalam format sufistik ajarannya. Mulkhan mengangkat pemikiran-pemikiran yang 'berbau' pluralisme, tetapi tidak memberinya label dan menentukan karakteristiknya. Dengan kata lain, Mulkhan belum membahas secara detail mengenai pemikiran pluralisme Syekh Siti Jenar. Selanjutnya masih tulisan Abdul Munir Mulkhan, Seykh Siti Jenar, Pergumulan Islam-Jawa (1999). Dalam bukunya ini, ia menggambarkan sosok Syekh Siti Jenar sebagai tokoh yang kontroversial sekaligus legendaris dalam sejarah Islam di Jawa, karena "pembangkangan tasawuf"-nya dan mitos kesaktian yang dimilikinya. Mulkhan mencoba memahami secara lebih jernih, konteks peristiwa penghukuman mati Syekh Siti Jenar yang dianggap menyimpang dari ajaran Islam oleh Dewan Wali Songo. Penulis secara kritis melihat ketegangan internal dan eksternal yang terjadi masa itu. Ketegangan itu berkaitan dengan pelbagai kelompok dan kepentingan yang saling bersinggungan dan hendak mengambil tempat utama dalam peta politik. Secara singkat dan hati-hati, penulis menguraikan ajaran Siti Jenar dan mengkritisinya dalam tradisi sufistik Islam dan filsafat Barat. Kemudian, ditunjukkan bagaimana Siti Jenar menerapkan ajarannya dan akhirnya berhadapan dengan kekuatan ulama paling dominan, Wali Songo. Kehadiran Siti Jenar dengan ajarannya yang berbeda dari 
"kebenaran" yang digariskan Wali Songo menjadi ganjalan besar, baik untuk penyebarluasan Islam maupun pengaruh politik Wali Songo sendiri.

Muhammad Sholikhin melalui hasil risetnya dalam rangka menyelesaikan program doktoral di UIN Sunan Kalijaga Jogyakarta, membahas tentang Syekh Siti Jenar secara mendalam dan hasil riset itu disajikan dalam bentuk buku, yang diterbitkan oleh Narasi Jogyakarta dengan judul, Sufisme Syekh Siti Jenar (2004). Dalam karyanya ini, Sholikhin menyoroti sosok Syekh Siti Jenar dalam bentuk biografi lengkap, sistematisasi dan rekonstruksi ajaran otentik Syekh Siti Jenar dalam nuansa mistik kejawen dan spiritualitas Sang wali nyentrik, yang menghadirkan kearifan spiritual Islam di Tanah Jawa. Sholikhin mengupas tujuan utama ajaran Syekh Siti Jenar, yaitu mengajak manusia selalu tumbuh berkembang seperti pohon Sidratul Muntaha; selalu aktif, progresif dan positif; membangkitkan Ingsun Sejati melalui tauhid al-wujud atau yang dikenal secara lokal dengan Manunggaling Kawula Gusti. Gerakan yang dilakukan Syekh Siti Jenar bersumbu pada pembebasan kultural, pembebasan kemanusiaan dari kungkungan struktur politik berdalih agama sekaligus pembebasan dari pasungan keagamaan yang formalistik.

Ahmad Chodjim dalam bukunya, Syekh Siti Jenar, Makna "Kematian" (2002). Dalam karyanya ini, Chodjim mengungkapkan, bahwa Islam yang dipahami Syekh Siti Jenar adalah Islam yang lebih mengedepankan atau menekankan penghayatan batin (esoteris), sedangkan dalam ajaranya lebih kentara nuansa sinkretisme. Dalam karya ini, Chodjim ingin mengajak kita untuk menyelami khazanah kearifan tradisional tentang rahasia alam, hidup, akal budi, hakikat dan eksistensi manusia, yang diperkaya dengan argumentasi keagamaan, dan sekaligus menggugah kita untuk berpikir kritis, agar perbedaan pandangan bisa dirasakan sebagai rahmat. Ia menggambarkan sosok Syekh Siti Jenar sebagai seorang pemikir yang lebih maju dari zamannya. Masih Achmad Chodjim dalam bukunya yang lain, Syekh Siti Jenar Makrifat dan Makna Kehidupan (2007). Buku ini merupakan kelanjutan dari buku yang disebut sebelumnya. Chodjim, dalam karyanya ini mengulas ajaran Syekh Siti Jenar yang mencakup permasalahan tauhid, akhlak, dan makrifat.

Sebagai data pendukung terdapat tulisan Anis Malik Thoha, Tren Pluralisme Agama (2005). Karyanya ini, merupakan pengembangan, penajaman, dan peng-up-datean pokok-pokok pemikiran dan kajian disertasinya, karya ini mengkaji pluralisme agama secara mendalam dan dikupas dengan pendekatan realitas di lapangan dan membandingkan pluralisme dengan konsep-konsep pelbagai agama serta menelaah penerapannya selama ini.

Penelitian-penelitian terdahulu tentang pemikiran Syekh Siti Jenar dalam lingkup biografik, sufistik dan sinkretisme ajarannya. Sementara dalam pembahasan ini, penulis lebih terfokus pada studi akar pemikiran pluralisme agama Syekh Siti Jenar, yang dalam penelitian sebelumnya dikategorikan sebagai corak pemikiran sufistik yang sinkretis. Melalui studi ini, penulis berusaha mengungkap bagaimana akar pemikiran pluralisme agama Syekh Siti Jenar, dan bagaimana corak pemikirannya berdasarkan klasifikasi pluralisme agama.

\section{METODE PENELITIAN}

Tulisan ini termasuk jenis penelitian kualitatif. Data-data yang diperlukan dalam penelitian diperoleh melalui studi kepustakaan. Data yang terhimpun diseleksi, lalu diklasifikasikan menjadi data primer dan data skunder. Data primer diambil dari naskah klasik "Serat Syekh Siti Jenar" yang merupakan tembang berbahasa Jawa yang terdiri 
dari 15 pupuh (bagian). Naskah yang ditulis ulang dan diterjemahkan oleh Raden Sosrowijoyo. Data sekunder diambil dari berbagai sumber, seperti buku dan pelbagai artikel di media cetak maupun elektronik, serta pelbagai literatur sejarah dan pemikiran yang relevan. Data yang sudah diklasifikasikan dianalisa menggunakan metode analisis isi dan deskriptif-analitik. Metode analisis isi digunakan untuk memperoleh makna dari pelbagai pemahaman mengenai isi dan makna dari pelbagai data penelitian, yang menghendaki pendekatan secara sistematis dan generalisasi, baik yang mengarah pada isi, maupun yang mengarah pada makna dalam konteks yang tepat dan berarti dalam proses penelitian dihasilkan. Metode deskriptif-analitik digunakan untuk menganalisa dan mendesripsikan temuan-temuan yang didapat.

\section{HASIL DAN PEMBAHASAN Asal-Usul Syekh Siti Jenar}

Syekh Siti Jenar memiliki sejumlah nama yang disandarkan kepadanya, yaitu San Ali, Syekh Abdul Jalil, Syekh Jabaranta; Prabu Satmata, Syekh Lemah Abang/Lemah Bang, Syekh Nurjati, Pangeran Panjunan, Sunan Sasmita, Syekh Siti Bang, Syekh Siti Brit, Syekh Siti Luhung, Sunan Kajenar, Syekh Wali Lanang Sejati, Syekh Jati Mulya, Syekh Sunyata Jati Murti Susuhunan Ing Lemah Abang (Sholikhin 2004, hal. 32) dan Pangeran Kajenar (Rinaldi 2008, hal. 54).

Dari nama-nama tersebut, nama Syekh Siti Jenar yang paling populer dan lebih dikenal banyak orang. Selain nama Syekh Siti Jenar, nama yang juga sering dipakai para ahli sejarah adalah Syekh Abdul Jalil. Hal ini disebabkan kebiasaan masyarakat Indonesia yang memanggil seseorang hanya dengan menyebut gelar orang tersebut sebagai penghormatan dan penghargaan sesuai dengan daerah asal, keilmuan, ajaran, serta gelar berdasarkan nasab atau keturunannya.

Nama Siti Jenar, sebenarnya mencerminkan ajaran yang disampaikannya kepada masyarakat. Siti Jenar berasal dari dua kata, Siti yang berarti tanah dan Jenar berarti merah, jadi secara harfiah, Siti Jenar berarti tanah merah. Nama Siti Jenar juga bersifat filosofis, karena manusia diciptakan dari tanah merah, yang pada akhirnya akan hancur, selebihnya adalah ruh Allah, yang akan berpisah dari jasad yang berasal dari tanah merah itu. Asal muasal kejadian manusia dan hakikatnya inilah yang menginspirasi ajaran Syekh Siti Jenar. Sudirman Tebba (2003) sebagaimana dikutip oleh Rinaldi (2008, hal. 58) menyatakan, "ada informasi yang menyebutkan bahwa kata "Siti Jenar" berasal dari bahasa Persia, Sidi yang artinya Tuan dan Jinnar [dzinnâr] yang artinya pemilik kekuatan bagaikan kekuatan api.

Dari nama-nama yang telah disebutkan sebelumnya, ditemukan juga istilah sunan, yaitu Sunan Kajenar dan Sunan Sasmita, begitu juga dengan penyebutan anggota Dewan Wali Songo, semuanya disebut dengan panggilan sunan. Hal ini dibantah oleh Simuh (2003, hal. 68) yang menyatakan bahwa ada dua naskah Jawa Islam yang ditulis pada masa Demak, yaitu naskah Jawa Islam dalam pembahasan ahli Belanda disebut Het Boek Van Bonang dan Een Javaans Geschrift uit de 16e Eeuw (Primbon Jawa Abad ke-16). Dalam sastra Jawa Islam zaman kerajaan Demak, belum muncul istilah Wali Songo dan sunan, yang ada hanya istilah guru atau syekh. Istilah sunan terdapat dalam karya sastra era Kartasura dan Surakarta akhir abad ke-17 dan abad ke-18. Selain itu, menurut Sholikhin (2004, hal.6): "Produk sastra Islam Jawa juga sangat terpengaruh oleh produkproduk sastra dan budaya dari era Sultan Agung" yang banyak melahirkan sastra babad. 
Jadi, penyebutan Siti Jenar dengan panggilan syekh lebih dapat diterima dari pada Sunan Kajenar/Jenar, begitu juga istilah sunan dalam menyebut wali songo.

Terdapat banyak versi mengenai asal-usul Syekh Siti Jenar. Berdasarkan kepustakaan yang ada, diceritakan "Siti Jenar adalah anak seorang raja pendeta elit Hindu-Budha di daerah Cirebon. Nama raja pendeta tersebut adalah Resi Bungsu”. Nama asli Syekh Siti Jenar adalah Hasan Ali alias Abdul Jalil atau ada yang menyebutnya Kasan Ngali Anshar/ Hasan Ali Anshar (Chodjim 2002, hal.4-5; Mulkhan 2004, hal.3; AlQalami 2005, hal.9, 14). Dia sangat kritis terhadap tatanan yang ada, yang menyebabkan ayahnya, sang raja pendeta itu tersinggung atas perilakunya, hingga suatu saat ayahnya marah besar, lalu menyihir sang anak menjadi seekor cacing, dan dibuang ke sungai. Pada waktu itu, Sunan Bonang sedang berperahu mengajarkan ilmu ghaib kepada Sunan Kalijaga, namun perahu yang dinaiki pun bocor dan ditambal dengan tanah merah yang kebetulan menjadi tempat Syekh Siti Jenar yang telah dishir menjadi cacing. Sunan Bonang mengetahui ada makhluk jadi-jadian yang menguping ajarannya, sang cacing pun diubah menjadi manusia. Sunan Bonanglah yang menamai cacing jadi-jadian tersebut dengan nama Siti Jenar (Dalhar Shodiq dalam Mulkhan 2004, hal. 3; Al-Qalami 2005, hal.29).

Kisah tentang asal- usul Syekh Siti Jenar di atas lebih bermuatan mitos, karena secara ilmiah, Syekh Siti Jenar yang berasal dari cacing akibat disihir ayahnya merupakan hal yang tidak bisa diterima akal dan tidak dapat dijadikan fakta yang valid. Selain itu, Syekh Siti Jenar adalah anak seorang Raja pendeta, hal ini juga merupakan sesuatu yang tidak jelas, apakah ayahnya pendeta atau raja?. Selanjutnya, raja pendeta yang dimaksud tersebut adalah raja pendeta Hindu-Budha, hal ini pun tidak jelas, sebab kedua agama tersebut berbeda. Selain itu, orang tuanya memberi nama dengan nama Hasan Ali Anshar. Hal ini sangat diragukan kebenarannya, karena Hasan Ali Anshar merupakan nama yang berasal dari Bahasa Arab, sedangkan orang tuanya menganut agama di luar Islam. Mengenai kejanggalan ini, (Sholikhin 2004, hal.38-39), menyatakan bahwa Hasan Ali yang diidentikan sebagai anak Resi Bungsu adalah Raden Anggaraksa putera tunggal Resi Bungsu, yang kemudian masuk Islam di Padepokan Giri Amparan Jati, dan namanya diganti dengan Hasan Ali oleh Syekh Datuk Kahfi. Nama yang mirip dengan nama kecil Syekh Siti Jenar, San Ali. Sedangkan nama Ali Anshar adalah sahabat Syekh Siti Jenar di Baghdad, sama-sama murid Syekh Abdul Malik al-Baghdadi. Dengan demikian, Syekh Siti Jenar jelas mempunyai nasab atau garis keturunan yang jelas.

Menurut Agus Sunyoto (2004, hal.90) Syekh Siti Jenar berasal dari Persia. Sunyoto menjelaskan, bahwa melalui pendekatan yang baik Syekh Siti Jenar berhasil menyebarkan Islam di Kawasan Pajang, dengan menyelipkan tradisi-tradisi keagamaan Persia dalam ajaran tasawuf yang diajarkannya. Pengaruh Syiah yang sampai saat ini masih terlihat diamalkan oleh masyarakat Islam di Jawa, khususnya di daerah pedalaman adalah memperingati kematian seseorang. Upacara Sradha, adalah upacara Hindu yang menghabiskan biaya yang sangat besar, lalu diubah dengan upacara memperingatinya pada hari ketiga, ketujuh dan keempat puluh, dengan membaca tahlil. Peristiwa memperingati kematian semacam ini, tidak hanya ada di daerah Jawa, namun juga menyebar ke luar Jawa, sebagaimana sering ditemui di desa-desa maupun di kota- kota besar, dimana masyarakat yang mengadakan peringatan hari ketiga, ketujuh, keempat puluh, keseratus dan keseribu hari.

Berdasarkan keterangan Rinkes, dikutip oleh Rahimsyah (tt, hal.137), Silsilah Syekh Siti Jenar berasal dari Nabi Muhammad Saw. melalui Fatimah, Imam Kusen (Husayn), Said Jenal Ngabidin (Zaenal Abidin), Muhammad Bakir (Al- Baqir), Syekh 
Datuk Ngisa Tuwu, Malaka (Syekh Datuk Isa), Syekh Datuk Salek (Shaleh), Seh Lemah Abang (Syekh Siti Jenar). Sholikhin (2004, hal.35-39) berhasil menelisik silsilah lengkap Syekh Siti Jenar, yaitu San Ali atau Syekh Abdul Jalil atau Syekh Siti Jenar bin Syekh Datuk Shalih (ulama asal Malaka) bin Syekh Isa al Alawi (menetap di Malaka) bin Ahmadsyah Jamaludin Husain (Kamboja menyebarkan Islam di sana/Mursyid Tarekat Syathariyah) bin Syekh Sayid Amir Maulana 'Abdullah Khannuddin (Mursyid Tharekat Syathariyah di Gujarat) bin Syekh Sayid Abdul Malik Al-Qazam/Azmat Khan (Seorang syekh kalangan 'Alawi kesohor di Ahmadabad, pindah dari Tarim bersama keluarganya ke India) bin Sayid Alawi (salah satu keluarga ulama terkenal di Hadramaut) bin Sayid Muhammad Shohibul Marbath bin Sayid 'Alawi Amir Al Faqih bin Sayid Muhammad bin Sayid 'Alwi (Hadramaut) bin Sayid Abdullah Ubadilla bin Sayid al Imam al Muhajir Ahmad al Husaini al-Faqih al-Muqaddam bin Syekh Sayid 'Isa al-Muhajir al-Bashari al'Alawi (keturunannya menyebar ke pelbagai pelosok dunia menyebarkan Agama Islam) bin Muhammad al-Rumi bin "Ali al-'Aridli bin Sayid Ja'far al Shadiq bin Sayidina Muhammad al-Baqir bin Sayidina Ali Zainal Abidin bin Imam al-Husain bin Ali bin Abi Thalib wa Fathimah al-Zahra binti Muhammad Saw.

Bersambungnya silsilahnya Syekh Siti Jenar dengan Rasulullah Saw. diakui para ulama nasab dari Yaman, Malaysia, Thailand dan Rabithah Alawiyah, Naqabatul Asyraf, serta Rabithah Azmatkhan. Adapun silsilah yang diakui adalah: Abdul Jalil /Syekh Siti Jenar bin Datuk Shaleh bin Sayid Abdul Malik bin Sayid Syaikh Husain Jamaluddin/Jumadil Kubro/Jamaluddin Akbar al-Khan (Gujarat, India) bin Sayid Ahmad Shah Jalal /Ahmad Jalaludin al-Khan bin Sayid Abdullah Azhmat Khan (India) bin Sayid Amir 'Abdul Malik al-Muhajir Azhmat Khan (Nasrabad) bin Sayid Alawi Ammil Faqih (Hadhramaut, Yaman) bin Muhammad Shahib al-Mirbath (lahir di Hadhramaut, Yaman dimakamkan di Oman) bin Sayid Ali Kholi' Qosim bin Sayid Alawi Ats-Tsani bin Sayid Muhammad Sohibus Saumi'ah bin Sayid Alawi Awwal bin Sayid Al-Imam 'Ubaidillah bin Ahmad al-Muhajir (Hadhramaut, Yaman) bin Sayid 'Isa Naqib al-Rumi (Basrah, Iraq) bin Sayid Muhammad al-Naqib bin Sayid Al-Imam Ali Uradhi bin Sayidina Ja'far asSodiq (Madinah, Saudi Arabia) bin Sayidina Muhammad al-Baqir bin Sayidina 'Ali Zainal 'Abidin (menikah dengan Fathimah binti Sayidina Hasan bin Ali bin Abi Tholib), kakak Imam Hussain bin Al-Imam Sayidina Hussain bin Imam Ali bin Abu Tholib dan Fatimah Az-Zahra binti Muhammad Saw.

Bila mengacu kepada silsilah Syekh Siti Jenar sebagaimana diungkapkan oleh Sholikhin dan silsilah yang diungkapkan oleh ulama nasab yang berasal dari Yaman, Malaysia dan Thailand, maka dapatlah ditarik suatu pemahaman, bahwa pada silsilah yang diajukan ulama nasab, tidak terdapat nama asli Syekh Siti Jenar/Abdul Jalil, sedangkan pada silsilah yang diungkapkan oleh Sholikhin disebutkan bahwa nama asli Syekh Siti Jenar adalah San Ali. Syekh Siti Jenar adalah keturunan ulama dan bukan berasal dari cacing sebagaimana yang telah disangka orang selama ini.

\section{Akar Pemikiran Pluralisme Agama Syekh Siti Jenar}

Pemahaman pluralisme dalam konteks ke-Indonesiaan masih memerlukan pengkajian tersendiri, karena Indonesia merupakan negara yang memiliki latar belakang situasi dan kondisi budaya yang berbeda, sementara itu, konsep pluralisme yang ada di Indonesia merupakan adopsi konsep-konsep pluralisme yang berasal dari intelektual barat, padahal, "ketika doktrin menyejarah dalam realitas kehidupan masyarakat, maka perhatian, pemahaman, penafsiran sepenuhnya bersandar pada realitas tersebut. Manusia yang satu dengan manusia yang lain berbeda dalam pemikiran maupun kehidupan sosial, ekonomi, 
budaya, politik dan geografis (Abdullah Idi 2010, hal. 4). Hal ini juga berimplikasi pada konsep pluralisme yang ada di Indonesia, yang jelas memiliki karakteristiknya sendiri.

Mengacu kepada pemahaman Islam Syekh Siti Jenar, Budhy Munawar Rahman dalam Chodjim (2002, hlm. vi) menyatakan, Islamnya Syekh Siti Jenar adalah Islam esoteris. Islam esoteris sendiri dimaknai sebagai suatu penafsiran Islam yang bersifat sufistik dan penuh dengan keterbukaan terhadap kearifan agama-agama. Dalam tataran yang lebih luas, Islam dipahami Syekh Siti Jenar melebihi simbol-simbolnya, melebihi segi lahiriah (syari'at), dan memasuki segi yang lebih mendalam-segi realitas tinggi (high reality)-yang bersifat batin. Lebih Jauh Munawar Rahman menyatakan, menurut paham Islam esoteris, manusia terdiri dari tiga unsur bertingkat, yaitu jasmani, nafsani dan ruhani. Tingkat terendah adalah jasmani, yaitu fisik, badan, atau tubuh manusia yang kelihatan sehari-hari (lahiriah). Tingkat kedua adalah nafsâni yaitu unsur manusia yang bersifat nafs, jiwa, atau psikologi. Segi ini tidak lagi bersifat jasmaniah, tapi sudah mulai batiniah, berkaitan dengan pikiran manusia (human mind). Tingkat yang paling tinggi adalah ruhâni (roh) atau spirit (Munawar Rahman, hal. vii). Ketiga hal inilah yang menjadi tema pokok pemikiran Syekh Siti Jenar.

Pada tataran jasmani, pemikiran Syekh Siti Jenar dapat dilacak melalui ajarannya, yang disadur oleh R. Sosrowijoyo dalam Serat Syekh Siti Jenar (1958): "Saya ini bukan budi, bukan angan-angan hati, bukan pikiran yang sadar, bukan niat, bukan udara, bukan angin, bukan panas, dan bukan kekosongan dan kehampaan. Wujud saya ini jasad, yang akhirnya menjadi jenazah, busuk bercampur tanah dan debu. Napas saya mengelilingi dunia, tanah, api, dan udara kembali ke tempat asalnya, sebab semuanya barang baru bukan asli" (pupuh sinom, bait 35). "Wa ammâ 'âlamu jawatuni (janazatun)": adapun yang ada di alam semesta ini berupa mayat. Makna tersebut sesuai sekali dengan kenyataan. Mayat-mayat berkeliaran dimana-mana, ke utara dan ke timur mencari rezeki, mencari makan dan sandang yang bagus dan permata serta perhiasan yang berkilauan, tanpa mengetahui bahwa mereka adalah mayat-mayat belaka. "Yang naik kereta, dokar, atau bendi itu juga mayat, meskipun sering kali berwatak keji terhadap sesamanya" (pupuh sinom, bait 55). "Hidup dipandangnya sebagai mati yang singgah dalam raganya. Ia berpikir bahwa ia tersesat dalam dunia ini. Neraka dahsyat, jasad yang mengandung panca indra, melihat dunia terbentang, matahari menyusup di langit, melihat dunia yang damai serta harta kekayaan, dianggap sebagai godaan kematian dalam dunia ini" (pupuh sinom, bait 57).

Syekh Siti Jenar memahami konsep jasmani sangat erat kaitannya dengan jasad, jasad erat kaitannya dengan konsep hidup dan mati. Pendapat Syekh Siti Jenar berbanding terbalik dengan pendapat umum yang ada. Menurutnya, hidup ini adalah kematian dan kehidupan sesungguhnya adalah kehidupan yang kekal dan abadi, tidak terikat kepada jasad, karena jasad akan lebur dengan tanah. Selain itu, roh manusia terkurung dalam badan, dan membawa nestapa bagi manusia sendiri. Menurut Syekh Siti Jenar, raga atau jasad merupakan sumber terjadinya banyak penyesatan. Jiwa yang terperangkap dalam jasad mengakibatkannya banyak mengalami penderitaan. Jiwa senantiasa diseret oleh raga untuk senantiasa menuruti segala perilaku yang dapat memuaskan kehendak raga. Misalnya jiwa tidak perlu makan. Ketika perut menjadi bagian dari raga pasti akan merasa lapar, maka jiwa dipaksa untuk memenuhi kebutuhan perut dan seterusnya. Untuk memenuhi segala keinginan yang bersifat ragawi, manusia rela melakukan apa saja sekalipun bertentangan dengan kehendak jiwa. Perilaku demikian bagi Syekh Siti Jenar menyebabkan jiwa mengalami siksaan dan penderitaan. 
Menurut Syekh Siti Jenar, surga dan neraka sudah ada di alam kematian (dunia) ini, "nampak dan terbentuk oleh kejadian yang nyata" (Dandang Gula, bait.30). Ia mengajukan tesisnya tersebut dengan argumen bahwa, "surga yang luhur terletak pada perasaan yang senang" (Dandang Gula, bait 30). Kemudian dalam bait yang sama, ia mengemukakan contoh realitas bahwa: "tidak kurang orang duduk dalam kereta yang bagus merasa sedih bahkan menangis tersedu-sedu, sedang "seorang pedagang keliling berjalan kaki sambil memikul barang dagangannya bernyanyi sepanjang jalan. "Ia menyanyikan berbagai macam lagu dengan suara yang mengalun merdu, ia menemukan surganya karena merasa senang dan bahagia" (Dandang Gula, bait 31). Pandangan Syekh Siti Jenar tersebut, jelas berbeda dengan cara pandang orang Islam pada umumnya. Menurutnya, surga dan neraka itu ditemukan manusia pada saat hidup di dunia ini, yang dinamakannya dengan alam kematian. Dia memandang bahwa kebahagiaan dan malapetaka adalah manifestasi dari surga dan neraka. Segala perbuatan baik yang menghasilkan ketentraman dan ketenangan dalam jiwa, itulah surga. Sebaliknya, segala perbuatan buruk yang menyebabkan kegelisahan dan penderitaan, baik bagi diri sendiri maupun bagi orang lain, itu adalah neraka. Jika mendalami pemikirannya yang menyatakan, bahwa surga dan neraka sudah tampak di dunia ini, yang demikian itu mungkin mengisyaratkan bahwa Syekh Siti Jenar lebih menekankan kehidupan sejati yang abadi. Pandangan Syekh Siti Jenar terhadap dunia memiliki kemiripan dengan ajaran Budha tentang dunia, bahwa "kehidupan di dunia ini adalah derita dan sengsara" (Rinaldi 2008, hal.157). Menurut Chodjim (2002, hal.47), pandangan Syekh Siti Jenar itu juga didasarkan pada( Q.S. az-Zumar: 30), yang menyebutkan bahwa "sesungguhnya engkau ini mayit dan mereka pun mayit".

Alam kematian (kubur), yang diungkapkan oleh Syekh Siti Jenar jika dikaji dengan pendekatan Bahasa Arab, berasal dari kata kerja: "qa-ba-ra" yang artinya memendam atau menyembunyikan. Kata "Qabr"yang dalam bentuk jamaknya "Qubûr" sebenarnya adalah tempat untuk memendam dan menyembunyikan sesuatu (Chodjim 2002, hal.24). Hal ini dapat dilihat dalam kehidupan dimana banyak manusia yang hidupnya menyembunyikan kebobrokan-kebobrokan dan kejahatan-kejahatan yang merugikan orang banyak tanpa mau mengakui dan merubahnya, perilaku seperti inilah yang menjadikan dunia sebagai alam kubur. Sebagai contoh, jika seseorang berbuat kejahatan dengan menghilangkan nyawa orang lain (membunuh) dan ia menyembunyikanya, maka ia akan merasa sangat tertekan, secara psikologis berimplikasi kepada perasaan yang tidak tenang dalam menjalani kehidupan, dihantui oleh rasa bersalah, dan rasa menderita. Akibat dari menyembunyikan kesalahan inilah yang membuat rasa senang bagai surga maupun rasa menderita laksana neraka.

Mengenai awak (jasad) yang bersifat bangkai, dalam artian ketika kita memasuki alam wujud, maka pasti kita digiring untuk menjadi bangkai, "kullu 'âlamin maujudun" (setiap alam ada eksistensi), dikomentari oleh Chodjim yang menyatakan bahwa, "sebenarnya filsafat Syekh Siti Jenar ini asli konsep Jawa. Alam atau kosmos butuh rupa, tetapi ia tidaklah berhenti pada "rupa" asalnya itu (Chodjim 2002, hal.28). Begitu juga "manusia, tatkala lahir sebagai bayi, manusia tidak tetap hidup sebagai bayi, ia tumbuh sebagai kanak-kanak, lalu remaja, pemuda, dewasa, tua renta, dan akhirnya menjadi bangkai" (Pupuh 2: Asmarandhana).

Dalam menjelaskan tentang kehadiran bayi di bumi sebagaimana dikutip di atas, Syekh Siti Jenar tidak membawa-bawa nama Tuhan. Dia hanya menyatakan bahwa bayi itu berasal dari desakan atau hadir secara alamiah. Tentu saja pendapat yang demikian bertentangan dengan pendapat umum yang menyakini bahwa kehadiran bayi atas dasar 
kehendak Tuhan. Akan tetapi mustahil bila Syekh Siti Jenar tidak mengerti kandungan al-Qur'an yang menyatakan bahwa Allah-lah yang menciptakan manusia. Ada kemungkinan Syekh Siti Jenar ingin mengajarkan isi kitab suci itu sebagaimana adanya. Dia tidak ingin dalam memahami kitab suci seperti anak-anak yang membutuhkan khayalan, perumpamaan dan anggapan-anggapan untuk memahaminya.

Bila membahas kehidupan dan kematian, maka ada dua unsur yang tidak bisa dipisahkan, yaitu jiwa dan roh. Selain jasmani ada badan kedua yang disebut "nafs", "jiwa", atau "sukma. "Ada yang menyebutnya mind atau pikiran, sedangkan badan ketiga yang paling halus adalah " $r u h$ ". Mengenai perbedaan antara nafs dan ruh, Chodjim (2002, hal. 109) berpendapat, bahwa orang Islam banyak menyamakan antara roh dengan nafs, padahal keduanya sangat berbeda. Jika kita membaca ayat-ayat al-Qur'an secara keseluruhan, akan jelas bedanya antara nafs dan roh. Roh tak pernah diberi atribut sengsara, menderita, mati dan sifat-sifat negatif lainnya. Jika orang matipun yang dikeluarkan dari jasad adalah nafs-nya bukan ruh-nya, yang merasakan suka cita adalah nafs-nya, bukan ruh-nya. Nafs merupakan kendaraan untuk hidup di atas planet dunia ini, dan dengan nafs-nya pula manusia berjalan menuju Tuhannya, hingga pada akhirnya ia menanggalkan segala atribut nafs-nya dan kembali kepada-Nya.

Mengenai nafs atau jiwa, Syekh Siti Jenar mengungkapkan pemikirannya dalam Pupuh 3, Dandang Gula: "Lain jika kita sejiwa dengan zat yang Maha Luhur. Ia gagah berani, Maha Sakti dalam syarak, menjelajahi alam semesta. Dia itu pangeran saya, yang menguasai dan memerintah saya, yang bersifat wahdaniyat, artinya yang menyatukan diri dengan ciptaan-Nya. Ia dapat abadi dan mengembara melebihi peluru atau anak sumpitan, bukan budi bukan nyawa, bukan hidup tanpa asal dari manapun, bukan pula kehendak tanpa tujuan" (Pupuh 3: Dandang Gula, bait 47). "Dia itu bersatu padu menjadi wujud saya, tiada susah payah, kodrat dan kehendak-Nya, pergi kemana saja tidak haus, tiada lelah tanpa penderitaan dan tiada lapar. Kekuasaan-Nya dan kemampuan-Nya, tiada kenal rintangan, sehingga pikiran keras dari keinginan luluh tidak berdaya. Maka timbullah dari jiwa raga saya kearifan dan kebijaksanaan tanpa saya ketahui keluar dan masuk-Nya, tahu-tahu saya menjumpai ia sudah ada di sana" (Pupuh 3: Dandang Gula, bait 48).

Dari pemikiran Syekh Siti Jenar mengenai jiwa, maka semakin jelas, bahwa dalam bertindak dan berbuat ia menuruti kehendak jiwanya, yaitu jiwa yang Maha Luhur. Ia memahami jiwanya menjadi rasa yang manunggal dengan jiwa yang Maha Luhur. Hal ini senada dengan pendapat Rinaldi (2008 hal.97) yang menyatakan bahwa menurut Syekh Siti Jenar, jiwa adalah suara hati manusia yang merupakan ungkapan dari Zat Tuhan yang harus dituruti dan ditaati perintahnya. Selain kehendak Tuhan, jiwa juga merupakan penjelmaan dari unsur Tuhan, yang berada di dalam jiwa, sehingga raga dipandang sebagai wajah Tuhan. Sifat jiwa yang berasal dari Tuhan itu akan kekal setelah manusia menemui kematian yang melepaskannya dari belenggu raganya. Ada satu lagi dimensi yang paling tinggi, yaitu dimensi rohani. Dalam pemikiran Syekh Siti Jenar, hakekat ruh diungkapkan dengan istilah manunggaling kawulo Gusti, yang juga menjadi maindstream ajarannya. Manunggaling kawulo Gusti merupakan pemikiran Syekh Siti Jenar dalam hal ketuhanan. Adapun pemikiran Syekh Siti Jenar tentang Tuhan terwakili dalam pernyataannya sebagai berikut: "Nama untuk menyebut Hyang Manon yang Maha Tahu, menyatukan diri hingga lenyap dan terasa dalam pribadi. Ya Dia, ya Saya" (pupuh 2, Asmarandana, bait 3). "Dia, itu yang bersatu padu menjadi wujud saya" (pupuh 3, Dandang Gula, bait 48). Dalam teks Asmaradana dari serat Suluk Wali Songo terbitan Tan Khoen Swie dalam P.J. Zoetmulder (1991, hal.358) yang menjelaskan ihwal manunggaling kawulo Gusti: "Marilah kita berbicara dengan terus terang. Aku ini Allah" 
(bait 20), "Akulah sebenarnya yang disebut Prabu Satmata (Hyang Manon, yang Maha Tahu) tidak ada lain yang bernama ilahi. Molana Maghrib berkata:"Tetapi (yang kau tunjukkan) disebut badan" (bait 21)."Saya menyampaikan ilmu (tertinggi) yang membahas ketunggalan. Ini bukan badan, selamanya bukan, karena badan tidak ada. Yang kita bicarakan ini adalah ilmu sejati dan untuk semua orang kita membuka tabir (membuka rahasia yang paling tersembunyi)" (bait 22).

Dari pemikirannya tentang ketuhanan tersebut dapat diketahui, bahwa Syekh Siti Jenar telah merasakan suatu kondisi batin, yang dalam istilah tasawuf tidak lagi merasakan nasut (dimensi kemanusiaan) dalam dirinya, melainkan sudah menjadi lahut (dimensi ketuhanan). Manunggaling Kawulo Gusti dalam Ilmu Tasawuf juga dipahami sebagai tahap fanâ' fillah (lebur terserap ke dalam Tuhan) dimana keakuan seseorang lenyap dan menjadi Aku Sejati dalam ketunggalan. Adapun yang menjadi kunci dalam pemikiran Syekh Siti jenar ini adalah ruh. Dalam al-Qur'an Allah Swt menjelaskan firmannya mengenai roh ini:"kemudian Dia sempurnakan kejadiannya dan Dia (Tuhan) tiupkan roh-Nya kepadanya"(As-Sajdah:9). Keterangan dalam Al-Qur'an ini merupakan titik tolak Syekh Siti Jenar dalam mengabstraksi konsepnya, bahwa ruh Tuhan berada dalam diri, sehingga dia adalah Tuhan, Tuhan adalah dia. Konsep ini terwujud ketika Syekh Siti Jenar mengawinkan pemikirannya dengan filsafat Budha maupun Hindu. Dengan demikian, manunggaling kawulo Gusti yang diusungnya, jelas dipengaruhi oleh beragam konsep yang diramunya menjadi satu. Salah satunya sebagaimana pendapat Soeprapto Nitihardjo sebagaimana dikutip oleh Chodjim (2002, hal.33) menyatakan bahwa manunggaling kawulo Gusti, menyatunya hamba dengan Tuhan adalah konsep Jawa. Konsep ini terekam pada tahun 911 SM, yaitu ketika lahirnya abjad Jawa oleh Mpu Ubayun.

Akar pemikiran manunggaling kawulo Gusti juga mendapatkan pengaruh dari agama Hindu, Budha, dan Islam. Dalam hal ini Chodjim (2002, hal.33) berpendapat, bahwa Siti Jenar tampaknya memilih yang asli Jawa, yaitu tekanannya pada atman, diri pribadi. Hal ini juga tidak bisa dilepaskan dari situasi dan kondisi budaya, sosio kemasyarakatan dimana Siti Jenar hidup.

Dalam Agama Hindu, manusia juga disebut Brahmapura (tempat kediaman Brahma atau Tuhan) juga ada ungkapan Aham Brahma Asmi (Aku adalah Brahma) atau Aham Atma Brahman (pribadiku adalah Brahman) serta Tat Twam Asi (aku adalah Aku). (Zazuli, 2011, hal.104). Yang dimaksudkan denga aku yang pertama bukan ego manusia dalam artian ke-aku-an manusianya, akan tetapi aku sebagai ruh suci dari Aku Sejati yang hakekatnya adalah percikan sinar Tuhan itu sendiri. Dengan demikian, berarti bukan Tuhan. Pendapat Zazuli (2011) ini diamini oleh Rinaldi (2008, hal.89) yang menyatakan, bahwa kesan yang tampak dari ajaran kesatuan ruh versi Syekh Siti Jenar ini identik dengan ajaran Hindu yang menegaskan bahwa manusia merupakan diri dari ruh universal sebagai penentu dari segala yang ada. Ruh manusia adalah keadaan yang tidak berubah, tidak berawal, tidak berakhir, tidak lupa, tidak tidur dan tanpa terikat dengan rangsangan indera yang melingkupi jasmani manusia. Dalam kitab Hindu, Bhagawad Gita dikatakan "Dalam segala makhluk dilihatnya atma (roh atau sinar Tuhan) itu ada dan segala makhluk itu berada pula dalam atma. Karena sendirinya menuntut yoga (persatuan dengan Tuhan) maka dilihatnya semuanya sama belaka" (bait IV: 29).

Ajaran Tao mengajarkan hakikat roh sebagai percikan sinar Tuhan, dimana dalam kitab Tao Teh Ching dinyatakan: "Barang siapa dapat melenyapkan sang aku bukan berarti kehilangan diri sendiri, bahkan sebaliknya ia akan menemukan diri sejati" (Zazuli 2011, hal. 105). Menyatu dengan Tao, dengan kehidupan membuatmu jadi langgeng- 
abadi. Walaupun badanmu musnah kau tak akan musnah (Anand Krishna, 1998 hal.65). Yang dimaksudkan dalam Tao Teh Ching, kau tidak musnah adalah ruh dari seseorang yang tidak akan musnah menjadi sejati dan abadi. Dalam ajaran agama Buddha roh juga disebut sebagai benih Buddha yang ada pada diri setiap insan (Boddhicita). Padmakumara Bodhisatva juga menjelaskan: "Aku Sejati adalah Buddha. Sifat sejati adalah Sinar Tuhan (Zazuli 2011, hal.106).

Semua hal tersebut di atas mendapatkan justifikasi fakta dalam Sejarah yang mengetengahkan suatu fase pembentukan buah pikiran Syekh Siti Jenar, karena pada saat di Padepokan Giri Amparan Jati Syekh Siti Jenar sangat menyenangi kerohanian sufi, hal ini dibuktikan ketika ia berniat mencari sangkan paran (hakekat/jati) dirinya, dan tempat yang dituju adalah daerah Pajajaran. Pajajaran pada waktu itu dipenuhi oleh para pertapa Budha dan para ahli yoga Hindu. Di Pajajaran menurut Sholikhin (2004, hal. 42-430; Damar Shasangka), Syekh Siti Jenar berhasil berguru kepada seorang yogi Hindhu. Dari Sang Yogi, Syekh Siti Jenar mendapatkan pelajaran yoga yang bersumber dari kitab Catur Viphala, sebuah sistem yoga yang juga dipelajari oleh Prabu Kertawijaya, Raja Majapahit. Menurut hemat penulis, mungkinkah seseorang yang telah mendapat dasardasar dan bekal ilmu agama dari sebuah pesantren kaliber Giri Amparan Jati, lalu belajar kepada yang bukan dari Islam? Memang hal itu tidak dapat diterima oleh logika, akan tetapi berdasarkan data yang diperoleh Sholikhin (2004, hal.42) berkenaan dengan kurikulum pendidikan yang diajarkan di Padepokan Giri Amparan Jati hanya ilmu alat saja, ada kemungkinan secara sosiologis seseorang akan mencari sesuatu yang baru, sebagai dorongan dari keinginan untuk mengetahui tentang sesuatu yang belum didapatkan jawabannya. Dalam hal ini, menurut Sholikhin tentang sangkan paran (hakekat) dirinya.

Inti ajaran dari Kitab Catur Viphala mencakup empat pokok laku utama. Pertama, nisprha, adalah suatu keadaan di mana tidak ada lagi sesuatu yg ingin dicapai manusia. Kedua, nirhana, adalah seseorang tidak lagi merasakan memiliki badan dan karenanya tidak ada lagi tujuan. Ketiga, niskala, adalah proses rohani tertinggi, "bersatu" dan melebur (fana') dengan Dia Yang Hampa, Dia yang tak terbayangkan, tak terpikirkan, tak terbandingkan. Dalam kondisi ini, "aku" menyatu dengan "Aku". Keempat, nirasraya, adalah suatu keadaan jiwa yang meninggalkan niskala dan melebur ke parama-laukika (fana' fi al-fana'), yakni dimensi tertinggi yang bebas dari segala bentuk keadaan, tak mempunyai ciri-ciri dan mengatasi "Aku" (Sholikin 2004, hal.42-43). Setelah mempelajari Kitab Catur Viphala, Syekh Siti Jenar mengalami pergolakan pemikiran dan pengalaman spiritual dari empat laku utama yang pada akhirnya menghasilkan empat rasa utama, yaitu heneng (tenang), hening (jernih), hunong (melihat), dan menang (kemenangan). Dari Kitab Catur Viphala ini juga Syekh Siti Jenar sebenarnya telah mempelajari ajaran Agama Hindu dan berupaya untuk mencari benang merah antara laku yoga yang dipahaminya dengan Islam sebagai keyakinannya.

Melalui fakta sejarah, menurut Sholikhin (2004, hal.43) terungkap, Syekh Siti Jenar pernah mempelajari pengetahuan tentang hakekat ketunggalan alam semesta, yang dijabarkan dari konsep nûrun 'alâ nûrin (cahaya Maha Cahaya), atau yang kemudian dikenal sebagai kosmologi emanasi (martabat tujuh) dengan berguru kepada Ario Damar di Palembang. Adapun ajaran martabat tujuh (tujuh tingkatan penampakan Tuhan) merupakan bagian dari ajaran wujudiyah dalam tasawuf. Munculnya paham ini dalam dunia tasawuf sebagai akibat dari adanya pengalaman fana' dan baqa' pada diri seorang sufi dalam pengembaraan sufinya. Konsep martabat tujuh menyatakan, "bahwa hanya Tuhan yang satu-satunya Wujud Hakiki. Agar ia dikenal, maka Tuhan menampakkan diri- 
Nya (tajalli) melalui tujuh tingkatan" (Sunyoto 2004, hal.97). Konsep ajaran martabat tujuh adalah pengembangan dari konsep tajalli Ibnu Arabi. Dasar pikirannya mengarah pada paham wahdatul wujud (union-mistik). Intinya adalah ajaran bahwa alam semesta termasuk di dalamnya manusia merupakan tajalli (penampakan luar) dari hakekat Tuhan yang bersifat mutlak, inilah yang mungkin dipelajari Syekh Siti Jenar dari Ario Damar.

Di Indonesia, ajaran tasawuf yang berkembang pada masa-masa permulaan, dapat dikategorikan kepada tipe mistik pertama. Tipe mistik ini sangat identik dengan paham wahdatul wujud atau wujudiyah yang merupakan pengembangan teori tajalliyat Ibnu Arabi dan dikembangkan oleh Ibnu Fadlullah al-Burhanpuri (wafat $1620 \mathrm{M}$ ) dalam karyanya Tuhfah al-Mursalah ilâ Ruh an-Naby. Doktrin wahdatul wujud atau wujudiyah ini berpusat pada ajaran tentang penciptaan alam dan manusia melalui penampakan diri Tuhan dalam tujuh martabat" (Azra dalam Fathurrahman 1999, hal.21; Azra 1995, hal.278). Sedangkan masuknya ajaran martabat tujuh ini ke Indonesia melalui Aceh pada abad ke-17, yang dikembangkan oleh Abdul Rauf Singkel (1617-1699 M).

Adapun inti ajaran Martabat Tujuh dibahas dalam (Sunyoto 2004, hal.97, Azhari dalam Zulkifli 1999, hal. 59-60) adalah: Pertama, lâ ta'ayyun (tiada nyata akan kenyataannya) dan ithlaq yang disebut "martabat ahadiyyah" adalah martabat yang menjelaskan zat Allah semata. Wujud zat Allah yang wajib al-Wujûd al-Ghani alMuthlaq. Dalam hal ini akal tidak bisa mengetahui-Nya karena zat Allah tidak diberi sifat ataupun nama. Kedua, at-ta'ayyun al-awwal, (kenyataan pertama) yang disebut dengan "martabat al-wahdah."yang disebut demikian itu adalah sifat Allah, pada tahapan ini/ kenyataan pertama ini, akal baru bisa mengetahui sifat Allah, sifat salbiyah dan sifat wujudiyyah, ini juga berarti wujud Dzat Allah yang sifatnya ijmâli, martabat ini juga menjadi awal mula hakikat Muhammad. Semua hakikat masih berkumpul dalam martabat wahdat dan belum terpisah-pisah. Dia diibaratkan tinta dalam wadahnya. Semua huruf terkumpul di dalam tinta, huruf yang satu belum dibedakan dengan huruf yang lain. Ketiga, wahidiyah atau kenyataan kedua (ta'ayyun tsâni). Pada tingkatan ini Allah dapat dikenal oleh akal melalui asmâ-Nya, yang terhimpun kepadanya namanya yang sembilan puluh sembilan, sebab asmâ-Nya itulah yang menunjukkan zat-Nya. Martabat ketiga ini juga adalah a'yun tsabitah yaitu awal mula kenyataan haqiqah al-insan (hakekat manusia). Ketiga martabat atau tingkat tersebut di atas adalah qadim (tidak bermula) dan baqâ (kekal selamanya). Urutan keberadaannya bukan dari sisi zaman atau waktu, tetapi hanya dari sisi akal.

Keempat, 'âlam arwah. Itulah pokok permulaan segala nyawa, baik bagi manusia, maupun bagi makhluk lain. Nyawa yang pertama kali dijadikan Tuhan adalah nyawa Nabi Muhammad Saw. dan digelari "abu al-arwah' artinya bapak segala nyawa. Seratus dua puluh tujuh ribu tahun sesudahnya barulah diciptakan roh yang lain. Segala sesuatu yang diciptakan sesudahnya adalah karena roh Muhammad. Dinamakan ruh dalam Bahasa Arab karena ia pergi-pulang, maksudnya roh ini datang dan pergi pada jasad. Jasad akan hidup bila di datangi roh dan akan mati bila ditinggalkan roh. Kelima,'âlam mitsal, yaitu perumpamaan segala keadaan selain keadaan Tuhan. Segala sesuatu selain Tuhan ada perumpamaannya dalam alam misal ini. Karena hanyalah sebagai perumpamaan, alam misal ini keadaannya halus, tidak dapat dicapai oleh panca indra. Keenam, 'âlam ajsâm ('âlam Syahâdah) dan 'âlam al-mulk, yaitu segala keadaan yang nyata dan dapat dilihat dengan panca indra, seperti tanah, batu, awan, air dan segala keadaan yang dapat dibagi dan disusun. Ia juga disebut alam segala jisim yang kasar. Ketujuh, 'âlam insani, yaitu yang disebut manusia. Alam ini disebut pula martabat 
jam 'iyyat, yaitu tingkat yang mengumpulkan segala dalil, yaitu sifat jalâl dan jamâl. Pada manusia itu berkumpul dua perumpamaan, yaitu al-Haqq (Tuhan) dan al-khalq (ciptaan).

Apa yang dipelajari Syekh Siti Jenar belum menjadi konsep martabat tujuh secara utuh seperti di atas. Karena konsep nûrun 'alâ nûrin (cahaya Maha Cahaya) yang dipelajari Syekh Siti Jenar berupa tiga tingkatan penampakan Tuhan; yaitu, ahadiyah, alwahdah, dan tajallî Syuhûdi. Pemahaman Syekh Siti Jenar terhadap hal inilah nantinya memengaruhi pengalaman-pengalaman sufinya, hingga sampailah ia pada pengalaman rohani yang melahirkan konsep mistik, manunggaling kawulo Gusti. Pemahamam Syekh Siti Jenar terhadap cikal bakal konsep ajaran martabat tujuh yang telah dipelajarinya ini pun memiliki akar ajaran dalam Filsafat Jawa, Hindu, dan Budha (Zazuli 2011, hal.129,130,131).

Pandangan Syekh Siti Jenar tentang agama dapat mengacu kepada Serat Syekh Siti Jenar saduran R. Sosrowidjojo (1958): "Sambil menantikan datangnya malam, ki Ageng Pengging menguraikan agama Hindu dan Budha, sedang Siti Jenar menyampaikan ajaran Islam. Ki Ageng Pengging mendengarkan dengan penuh minat utaian Syekh Siti Jenar yang menerangkan dengan jelas dan teratur sehingga mudah diikuti. Mereka akhirnya berkesimpulan, bahwa meskipun agama yang mereka anut berbeda, tapi pada hakikatnya kedua agama tersebut adalah sama" (Pupuh 1, sinom, bait 8). "Tiga hari tiga malam Syekh Siti Jenar berada di Pengging membahas Hindu, Budha, dan Islam dengan Ki Kebo Kenongo, akhirnya mereka menemukan kesepakatan, antara kepercayaan mereka tiada bedanya" (Pupuh 1, sinom, bait 16). "Manusia yang melebihi sesamanya, memiliki dua puluh sifat, sehingga dalam hal ini antara Hindu, Budha, Jawa dan Islam sudah campur" (pupuh 2, Asmarandana, bait 5)".

Dari Serat Syekh Siti Jenar di atas dapat dimengerti, bahwa dalam menafsirkan ajaran agamanya, baik Ki Kebo Kenongo maupun Syekh Siti Jenar menafsirkan ajaran agamanya dengan penafsiran yang bersifat mistis, penuh keterbukaan terhadap kearifan agama-agama. Agama dipahami melebihi simbol-simbolnya. Agama dipahami melebihi segi lahiriah (syari'at), memasuki segi yang lebih mendalam-segi realitas tinggi (high reality)-yang bersifat batin. Pendapat ini diperkuat oleh Chodjim (2002) yang menyatakan, bagi Syekh Siti Jenar manusia harus diajar dan dididik seperti apa adanya, orang yang sudah menerima Tuhan dengan sebutan Hyang Widhi tak perlu dipaksa untuk menyebut Allah. Karena Hyang Widhi, Hyang Manon (yang Maha Melihat), Gusti Kang Akarya Jagat, atau Allah semua itu hanya sebutan bagi Tuhan Yang Maha Esa. Manusia menyebut nama-Nya menurut bahasanya, budaya tempat hidupnya (Codjim 2002, hal.43).

Pandangan Syekh Siti Jenar di atas tidak bisa dipisahkan dari pengaruh ajaran tasawuf Al-Hallâj (858-922 M), yaitu teori hulûl, dan terutama teori nûr Muhammad-nya yang memiliki kaitan langsung dengan konsep wahdatul adyân. Menurut Al-Hallaj, nûr Muhammad merupakan jalan hidayah (petunjuk) dari semua nabi, pada prinsipnya sama. Semua nabi merupakan emanasi wujud, sebagaimana dirumuskan dalam teori hulûl-nya. Oleh karena itu, pada dasarnya agama-agama berasal dari dan akan kembali kepada pokok yang satu, karena memancar dari cahaya yang satu. Menurut Usman (tt, hal.12) bagi AlHallaj, perbedaan yang ada dalam agama-agama hanya sekedar perbedaan bentuk dan namanya, sedangkan hakekatnya sama, bertujuan sama, yakni mengabdi kepada Tuhan yang sama pula. Jadi, semua agama, apa pun namanya berasal dari Tuhan yang sama dan bertujuan sama.

Selain dari yang telah dikemukakan di atas, lahirnya ajaran Manunggaling Kawulo Gusti dan pluralisme agama Syekh Siti Jenar secara umum juga berakar dari 
kitab-kitab yang dipelajarinya selama melaksanakan perjalanan sufinya di Baghdad (Sholikhin 2004, hal.45). Dari buku-buku yang dibacanya ini jelas akan berimplikasi pada filosofi pemikiran mistiknya, karena buku-buku tersebut adalah buku-buku yang terkenal pada zamannya dan pengarangnya pun adalah para sufi sekaligus filosof. Kitab Thawâsîn yang dikarang al-Hallâj, memuat ajaran tentang wahdatul adyân (Usman tt, hal.35). Wahdatul adyân adalah suatu konsep yang menyatakan bahwa semua agama pada hakikatnya adalah sama. Adapun pandangan Al-Hallaj yang kontroversial adalah konsep penjelmaan Tuhan ke dalam diri manusia (hulûl), asal-usul kejadian alam semesta dari nûr Muhammad (cahaya Muhammad) dan konsep kesatuan agama (wahdat al-adyân) (Usman tt, hal.36). Dari Thawâsin-nya Al-Hallâj, Syekh Siti Jenar memahami bahwa sumber agama adalah satu, yakni Tuhan yang sama. Pada dasarnya agama yang dipeluk seseorang merupakan hasil pilihan dan kehendak Tuhan, bukan sepenuhnya pilihan manusia sendiri (Usman tt, hal.14).

Selanjutnya adalah Abu Yazid al-Bustami, karena dari mulutnya kerap kali keluar kata-kata yang berisi kepercayaan bahwasannya hamba dan Tuhan sewaktu-waktu bisa berpadu menjadi satu, inilah mazhab yang dinamai hulûl atau berpadu. Setengah dari perkataannya: tidak ada Tuhan melainkan Saya, sembahlah Saya, amat sucilah Saya, alangkah besar kuasa-Ku (Hamka 1980, hal. 96-97). Dari sini Syekh Siti Jenar memahami bahwa dalam keadaan tertentu hulûl dapat terjadi. Selain itu, Syekh Siti Jenar juga mendalami pemikiran Abu Bakar al-Kalabadzi (w.di Bukhara 380 H/990 M atau 384 H/994 M) dalam kitabnya Kitab at-Ta'arruf li Mazhab Ahl at-Tasawwuf (Pengantar ke Arah Mazhab-Mazhab Ahli Tasawuf), berisi 75 pasal yang menjelaskan ajaran-ajaran dan pengalaman-pengalaman rohaniah para sufi (Azra et. al, 2003, hal.36-37). Dari sini Syekh Siti Jenar memahami pelbagai macam aliran tasawuf, membuatnya berpandangan inklusif, dalam artian semua ajaran tasawuf memiliki pandangan yang berbeda namun bukan berarti salah.

\section{Corak Pluralisme Agama Syekh Siti Jenar}

Berbicara mengenai corak pemikiran pluralisme agama Syekh Siti Jenar, hendaknya mengacu kepada ajarannya sebagaimana dalam uraian terdahulu. Pemikiran pluralisme agama Syekh Siti Jenar tidak dapat dilepaskan dari setting sejarah keberadaan agamaagama pada waktu itu, interaksi setiap agama dengan agama lain, baik pada ranah kultural maupun politik. Bila melihat latar belakang yang mendasari kepercayaan orang Jawa (kejawen atau javanisme) yang berkeyakinan, bahwa segala sesuatu yang ada di dunia ini pada hakekatnya satu, atau satu kesatuan hidup. Diperkirakan unsur-unsur ini berasal dari masa Hindu-Budha dalam sejarah Jawa yang berbaur dalam satu filsafat, (Simuh 2003, hal.17,19). Jadi komponen Hindhu-Budha dan Filsafat merupakan unsur-unsur yang membentuk kepercayaan orang Jawa yang dipadukan dengan pemikiran asli Jawa sendiri. Fakta ini juga didukung oleh pencitraan agama Hindhu dan Budha di Indonesia dalam setting sejarahnya. Antara abad ke-13 dan abad ke-16, hubungan damai meningkat di antara kaum muslim dan agama-agama di India, Birma, Malaysia, Sumatera dan Jawa. Dalam konteks Indonesia, Islam datang setelah agama Hindhu dan Budha berdiri kokoh, yang disokong oleh Kerajaan Majapahit dan Kerajaan Sriwijaya (Ghazali 2009, hal.97). Dalam rentang sejarah selanjutnya, setelah kedua kerajaan besar itu runtuh, Jawa dan Sumatera dikuasai oleh kerajaan-kerajaan Islam, yang diikuti oleh perpindahan agama penduduknya. Namun, dalam proses konversi agama itu, sejarah membuktikan dan mencatat, tidak terjadi konflik agama, karena terdapat titik temu teologis antara mistisme Hindhu-Budha dan Islam. Banyak orang berkata, Islam di Indonesia yang berkembang 
saat itu adalah Islam yang bercampur dengan tradisi dan dogma-dogma Hindhu-Budha (Ghazali 2009, hal.96).

Ada satu hal yang perlu dipahami, bahwa dalam tahapan-tahapan pemikirannya, Syekh Siti Jenar telah mengemukakan satu argumen mistik yang sinkretik, pluralisme agama. Jika pemikiran-pemikiran Syekh Siti Jenar dikaitkan dengan fase-fase sejarah yang dilaluinya beserta faktor-faktor yang melatarbelakangi ajarannya, maka pluralisme agama yang yang diusung oleh Syekh Siti Jenar bercorak hikmah abadi, juga bercorak sinkretisme. Hal ini tidak bisa dipisahkan dari titik temu teologis sebagaimana yang dinyatakan oleh Moqsith Ghazali (2009, hal.96), yaitu pertemuan antara mistisme HinduBudha dan Mistisme Islam. Berkaitan dengan pemikiran Syekh Siti Jenar tentu tidak bisa pula dilepaskan dengan manunggaling kawulo Gusti (menyatunya hamba dengan Tuhan), dimana konsep ini adalah konsep Jawa. Suprapto Nitihardjo sebagaimana dikutip Chodjim (2002, hal.33), konsep ini terekam pada tahun 911 SM, yaitu ketika lahirnya abjad Jawa oleh Mpu Ubayun. Memang dalam penerapan konsep tersebut, ada yang mendapat pengaruh dari Agama Hindu, Budha, dan Islam. Namun paham Manunggaling Kawulo Gusti Syekh Siti Jenar jelas berbeda dengan konsep Manunggaling yang asli jawa.

Konsep Manunggaling Asli Jawa selain berakar pada pandangan falsafah orang Jawa sendiri, juga tidak bisa dipisahkan dari pengaruh Hindu dan Budha. Pada masa awal kedatangan Islam di Nusantara, bahwa Islam yang tumbuh dan berkembang bercorak tasawuf. Pandangan Hidup masyarakat Jawa yang sebelumnya bersifat mistik dapat sejalan, untuk kemudian mengakui bahwa Islam Tasawuf menjadi keyakinan mereka (Simuh 2003, hal.24). Jadi titik temu ketiga agama tersebut adalah terletak pada falsafah masing-masing agama yang menitik beratkan pada mistisme yang disinkretisasikan. Selanjutnya dinyatakan oleh Chodjim (2002, hal. 39) bahwa ajaran-ajaran agama di Jawa, sebelum Islam datang, memang sudah mapan. Hindu dan Budha, masing-masing sudah mempunyai candi. Mereka pun hidup berdampingan dengan damai "Bhineka Tunggal Ika, Tan Hana Dharma Mangarwa". Inilah ungkapan persatuan Nusantara.

Jika dipahami secara filosofis, kemungkinan peletak dasar Bhineka Tunggal Ika pada masanya memahami kenyataan pluralitas tidak hanya terbatas pada kebudayaan dan adat istiadat saja, namun juga menjadikan keberadaan agama sebagai tolok ukur yang harus dipikirkan, maka pemahaman Pluralisme asli Indonesia sebenarnya digali dari falsafah Bhineka Tunggal Ika. Ada hal yang unik dalam menyikapi hal ini, dewasa ini pemahaman pluralisme yang dikenal mengedepankan suatu istilah tiga agama satu Tuhan Sebagaimana dinyatakan oleh Nurcholish Madjid dan kawan-kawan, namun agama yang mereka maksud adalah agama samawi (semitis) dengan konsep pluralisme yang mengelaborasi konsep-konsep Barat, maka dalam konteks corak asli pluralisme Indonesia versi Syekh Siti Jenar penulis juga cenderung menyebutnya dengan tiga agama satu Tuhan dalam artian agama yang dimaksud adalah perpaduan dua agama ardhî (Budha dan Hindu) dan satu agama samawî (Islam) yang dilebur dalam pemikiran falsafah Jawa.

Berdasarkan uraian di atas, bila pemikiran Syekh Siti jenar dihubungkan dengan pluralisme agama, khusunya trend pluralisme agama yang berkembang dewasa ini, maka pluralisme yang dikemukakan Syekh Jenar memiliki dua corak yang integratif; pertama, termasuk ke dalam corak pluralisme hikmah abadi, sebab Syekh Siti Jenar dalam memahami pengalaman batinnya memakai pendekatan esoteris, dimana hakikat batiniah yang dikedepankan, meskipun secara lahiriah agama berbeda-beda, alan tetapi secara batiniah semua agama menuju pada yang satu yakni Tuhan; kedua, wajah pluralisme dalam pemikiran Syekh Siti Jenar berakar dari tiga pandangan agama yaitu Budha, Hindu, 
dan Islam. Syekh Siti Jenar dalam "meramu" pemikirannya telah melakukan sinkretisasi ajaran dari ketiga agama tersebut, yang di"kemas" dengan filsafat Jawa, sehingga mengkristal ke dalam ajaran mistiknya yang khas, Manunggaling Kawulo Gusti.

\section{KESIMPULAN}

Dari pembahasan yang telah diuraikan sebelumnya, maka dapat diketengahkan simpulan sebagai berikut:

Pertama, Akar pemikiran pluralisme agama Syekh Siti Jenar berkait berkelindan dengan pluralitas jaringan keilmuannya, seperti ajaran Budha melalui kitab Catur Vhipala, Yoga Hindu, mistisme Islam, dan filsafat Jawa, yang "mengilhami" konsepkonsep dan teori-teorinya yang terejawantahkan dalam format mistisme yang dikembangkannya, yang cenderung masuk dalam klasifikasi pluralisme agama.

Kedua, pemikiran pluralisme agama Syekh Siti Jenar merupakan rintisan pluralisme agama yang bercorak hikmah abadi-sinkretisme. Dikategorikan hikmah abadi, karena pandangannya yang memposisikan antara Islam dengan agama-agama lain (Hindu dan Budha) sama pada level esoterik. Perbedaan itu hanya terjadi pada level eksoterik agama-agama tersebut; seperti nama, bahasa dan tatanannya. Dikategorikan sinkretisme, karena pemikiran-pemikirannya sebagai wujud dari sinkretisasi yang ia lakukan antara ajaran Islam, Hindu, dan Budha yang dikemas dengan filsafat Jawa.

Berdasarkan apa yang telah diungkapkan di atas, mengenai Akar Pemikiran Pluralisme Agama Syekh Siti Jenar, penulis perlu untuk memberikan beberapa saran berkenaan dengan hasil penelitian tersebut. Pertama, munculnya pemikiran Syekh Siti Jenar yang dapat dikategorikan pluralisme agama ini tidak serta merta terjadi, akan tetapi melibatkan latar belakang sosial keagamaan yang mempengaruhinya. Dia seorang yang muslim, namun konsep-konsep dan teori-teori yang diejawantahkannya dalam format mistisme, jelas sinkretisasi ajaran agama-agama yang tidak perlu diyakini kebenarannya, apalagi untuk diamalkan. Kedua, nilai-nilai pluralisme agama yang berasal dari pemikiran Syekh Siti Jenar yang memposisikan kebenaran semua agama adalah sama, tentu tidak boleh diterima begitu saja apalagi diyakini. Berkaitan dengan masalah akidah, tentu setiap muslim diharuskan bersifat ekslusif, prinsip semacam ini telah digariskan Allah dalam Al-Qur'an, lakum dînukum waliyadîn (bagimu agamamu, dan bagiku agamaku). Islam hanya mengajarkan prinsip tasamuh (toleransi), sebatas saling menghargai untuk kemaslahatan sosial. 


\section{DAFTAR PUSTAKA}

Al-Qalami, Abu Fajar t.t. Ajaran Makrifat Syekh Siti Jenar. Pustaka Media, Surabaya. Azra Azyumardi. (2002). Konflik Baru Antar Peradaban; Globalisasi, Radikalisme \& Pluralitas (cetakan pertama), PT. RajaGrafindo Persada, Jakarta.

Chodjim, Ahmad. (2004). Syekh Siti Jenar Makna "Kematian" (cetakan pertama), PT. Serambi Ilmu Semesta, Jakarta.

Chodjim, Ahmad. (2010). Syekh Siti Jenar Makrifat dan Makna Kehidupan (cetakan kelima), PT. Serambi Ilmu Semesta, Jakarta.

Ghazali, Abd. Moqsith. (2009). Argumen Pluralisme Agama (cetakan pertama), KataKita, Depok.

Hamkah. (1951). Tasawuf Perkembangan dan Pemurniannya, Yayasan Nurul Islam, Jakarta.

Idi, Abdullah (2010). Asimilasi Cina Melayu di Bangka, Tiara Wacana: Yogyakarta.

Krishna, Anand (1998). Tao The Ching, PT. Gramedia Pustaka Utama, Jakarta

Majid, Nurcholis at.all. 2004. Fiqih Lintas Agama. Paramadina, Jakarta. M.A,

Mulkhan, Abdul Munir (1999). Pergumulan Islam-Jawa, Yayasan Bentang Budaya, Yogyakarta.

Mulkhan, Abdul Munir 2004. Ajaran dan Jalan Kematian Syekh Siti Jenar. Kreasi Wacana, Yogyakarta.

Murtadho, M. (2002). Islam Jawa Keluar dari Kemelut Santri vs Abangan (cetakan pertama), Lappera Pustaka Utama, Yogyakarta.

Prabhupada, Sri Srimad A.C. Bhaktivedanta Swami (tanpa tahun terbit). Bhagawad Gita Menurut Aslinya, Hanuman Sakti, tanpa tempat terbit.

Rahimsyah, MB. t.t. Kisah dan Ajaran Syekh Siti Jenar, Karya Agung, Surabaya.

Rinaldi, Jhon. (2008). Syekh Siti Jenar Dunia Sebagai Alam Kubur, Pustaka Pelajar: Yogyakarta.

Sasrowijoyo, Raden. (1958). Serat Syekh Siti Jenar. Kulawanga Brata Kesawa, Jogdjakarta.

Serat Siti Jenar t.t. (Perpustakaan Sono Budoyo, Nomor Katalog SB. 137).

Sholihin, Muhammad. (2004). Sufisme Syekh Siti Jenar: Kajian Kitab Serat dan Suluk Siti Jenar. Narasi, Yogyakarta.

Simuh. (2003). Islam dan Pergumulan Budaya Jawa, Teraju, Jakarta.

Sunyoto, Agus. (2004). Suluk Abdul Jalil Perjalanan Ruhani Syaikh Siti Jenar, LKIS: Yogyakarta.

Thoha, Anis Malik (2005). Tren Pluralisme Agama Tinjauan Kritis. Perspektif, Jakarta. Usman, Fathimah tt. Wahdat Al-Adyan; Dialog Pluralisme Agama, LkiS, Semarang.

Zazuli, Mohammad. (2011). Syekh Siti Jenar; Mengungkap Misteri dan Rahasia Kehidupan, Serambi Ilmu Semesta, Jakarta.

Zoetmulder, P.J. (1991). Manunggaling Kawula Gusti; Pantheisme dan Monisme dalam Sastra Suluk Jawa, (terjemahan Dick Hartoko), PT. Gramedia Pustaka Utama, Jakarta. 